\title{
Getting organized \\ Culture and nationalism in Bali, 1959-1965
}

\author{
I Nyoman Darma Putra
}

Studies of Indonesian cultural institutions and their associated political movements from 1950 to 1965 focus mainly on a single organization - namely Lembaga Kebudajaan Rakjat (LEKRA, Institute of People's Culture) (Yahaya Ismail 1972; Foulcher 1986; Taufik Ismail and D.S. Moeljanto 1995). To some extent, such studies cover the 1963-1964 conflict between LEKRA and the group behind the Cultural Manifesto (Manifes Kebudayaan, disparagingly referred to as Manikebu by its opponents) (Foulcher 1969; 1994; Goenawan Mohamad 1988). Even then, however, most studies on LEKRA, including those that cover the conflict with the Cultural Manifesto, discuss activities at the national level and overlook what happened at the regional level. In general, existing studies provide an incomplete picture of arts and cultural movements and institutions in Indonesia during the 1950s and early 1960s.

The considerable attention given to LEKRA is understandable because this cultural organization, which was affiliated with the Partai Komunis Indonesia (PKI, Indonesian Communist Party) and had branches all over Indonesia, was highly organized, visible, and driven by a cultural political ideology that increasingly brought it into conflict with other cultural political groups and individual artists and writers who opposed its approach. It is arguable that LEKRA was the most influential cultural institution in Indonesia during this period. After the alleged Communist coup attempt in September 1965, and President Soekarno then deprived of effective power, LEKRA was banned by military decree in March 1966. Many of those who were members of, or accused of sympathy with LEKRA were brutally killed or jailed without trial. The controversial and tragic fate of LEKRA members and activists gives added importance to this cultural institution as a subject of study in various disciplines including literature, cultural history, and political and cultural violence. 
However, apart from LEKRA, there were many other cultural institutions in Indonesia during the Soekarno period, including Lembaga Seniman Budayawan Muslim Indonesia (LESBUMI, Institute of Indonesian Muslim Artists and Cultural Figures), Lembaga Kebudajaan Katolik Indonesia (LKKI, Indonesian Catholic Cultural Institute), Lembaga Kebudajaan Kristen Indonesia (LEKRINDO, Indonesian Protestant-Christian Cultural Institute), and Lembaga Kebudajaan Nasional (LKN, Institute of National Culture). Like LEKRA, these cultural organizations were also affiliated with particular political parties or religious organizations and had branches across Indonesia.

LKN, which was affiliated with the Partai Nasional Indonesia (PNI, Indonesian National Party) was one of the most important of these cultural institutions in terms of membership and national coverage. It had its central office in Jakarta and many branches spread throughout Indonesia ranging from provincial level down to district and village levels, parallel to the organizational structure of the PNI. The spread of LKN branches across Indonesia and its active role in serving the political goals of its parent organization paralleled the role of LEKRA during the debates surrounding the dynamic formation of Indonesian national culture from the late 1950 s to 1965 . Thus the role of LKN at the national as well as regional level cannot be ignored.

THE DISAPPEARANCE OF LKN

Unlike LEKRA, LKN has been under-represented in scholarly studies on the cultural history of Indonesia. Sutedja-Liem (2000) touches briefly on LKN in Bali in the context of conflict and cooperation between its members and other cultural organizations including LEKRA. But this discussion aims only to situate Balinese Indonesian-language poetry and a short story by the Balinese writer Rastha Sindhu in their social contexts. It does not claim to be a full exploration of the development and cultural activities of LKN Bali. In an earlier article dealing with the rise and fall of LEKRA in Bali (Darma Putra 2003), I discussed the conflict between LEKRA and LKN but explored more the development of LEKRA Bali rather than the development of the Balinese branch of LKN. While studies and publications on LEKRA continue to appear, especially the recent reproduction of literature by LEKRA members originally published in Harian Rakjat (Rhoma Yuliantri and Muhidin Dahlan 2008a, 2008b); and while recently there have been studies on other 
cultural institutions from the 1960s such as LESBUMI (Choirotun Chisaan 2008), there is virtually nothing dealing with LKN. In studies of Indonesian literature, culture and politics in the 1960s, LKN is rarely mentioned. In fact it could be said that LKN has almost disappeared from the history of Indonesian culture and politics.

As a first step towards rectifying this omission, and in an attempt to contribute a regional dimension to the nationally oriented studies of cultural institutions in Indonesia of the 1950-1965 period, this essay investigates the Bali branch of LKN. LKN Bali was an important branch of the organization in terms of its capacity to compete against the aggressiveness of LEKRA in Bali. Bali is an interesting case because, unlike Sumatra, Java and Sulawesi, ${ }^{1}$ the presence and role of Muslim and Christian cultural organizations at this time was minimal. LESBUMI and LKKI, for example, were present in Bali, but they were both small and had almost no solid organizational structure, unlike LEKRA and LKN. ${ }^{2}$ As the two dominant cultural organizations in Bali, LEKRA and LKN were involved in a constant power struggle to dominate cultural discourse and activities on the island, either through performance events or political rallies (Putu Setia 1987).

As LKN and LEKRA were both leftist in orientation, it is particularly interesting to see the points of convergence and conflict between them. After LEKRA was banned in 1966, LKN became the dominant cultural organization in Bali during the power transition from Soekarno to Suharto. This essay focuses on two main areas: first, the development of the Bali branch of LKN, its relationship with the Central LKN and with other cultural institutions in Bali and beyond; and second, the arts and cultural activities of LKN Bali. It aims to show how dynamic cultural activities were at a regional level in Indonesia between 1950 and 1965 and how national politics influenced such activities. I argue that the existence of LKN Bali enlivened cultural activities on the island, in that members of this organization made enthusiastic use of a variety of traditional and modern art forms to express a veritable fever of nationalistic sentiment during this period.

This essay also aims to contribute some of the material required for a broader study of LKN and its place in Indonesian cultural history of the 1950s and 1960s. It is mainly based on newspaper reports and interviews with writers and cultural activists in Bali during the

1 See Marije Plomp and Barbara Hatley in this volume for a discussion of cultural organizations, figures and activities in Medan and Makassar respectively.

2 Interview with Paulus Yos Adi Riyadi, Denpasar, 27-6-2009. He was a writer and former deputy chief of the Bali branch of the Catholic Party. His poetry from the 1960s is discussed below. 
period under investigation. ${ }^{3}$ However it does not pretend to be an exhaustive survey of newspaper reports from this period. What follows is a brief description of LKN and its principles as a national organization, followed by the development of the Bali branch of LKN and its cultural activities.

\section{CENTRAL LKN AND ITS PRINCIPLES}

LKN was established as a national cultural institution in 1959 at a congress held in Solo, Central Java. The Congress was deliberately timed to begin on 20 May to coincide with Hari Kebangkitan Nasional (National Awakening Day), to stress the importance of its nationalist spirit. ${ }^{4}$ The Congress lasted for three days, and was held in Solo not only because of its central location but also because Solo had long been recognized as a centre of art and culture. LEKRA had also held its national Congress in Solo between 22 and 28 January of the same year.

The Congress was initiated by the PNI as part of the implementation of its resolutions of December $1958,{ }^{5}$ as a demonstration of the party's commitment to the development of Indonesian national culture. For the PNI, the advancement of a nation depended on its cultural progress, and the Congress was held 'to unite arts and cultural organizations and individuals whose thoughts have proven or are expected to be in harmony with the ideas of the PNI in the field of culture' ${ }^{6}$ It is clear that the motivation for the Congress was the party's perception that a cultural organization promoting the ideals of Indonesian nationalism would serve the interests of the PNI in the same way that LEKRA supported PKI interests through its promotion of Marxist-oriented cultural expression. At the Congress, the young poet Sitor Situmorang (b. 1924), who was one of its initiators, was elected as the leader of LKN.

3 I would like to thank all participants in the Indonesian Cultural History Project especially Jennifer Lindsay who kindly shared with us numerous items from the magazine Budaya (19551958) and Michael Bodden who shared with me several relevant articles from Harian Rakjat. I am also grateful to Jennifer Lindsay, Barbara Hatley, Keith Foulcher and Maya Liem and all participants in the project workshop for their helpful comments on an earlier draft of the article.

4 National Awakening Day is an annual celebration that marks the founding in 1908 of Boedi Oetomo, the organization seen as the beginning of the Indonesian nationalist movement.

5 'Besok kongres LKN dimulai', Suluh Indonesia, 19-5-1959.

6 '[u]ntuk menjatukan organisasi2/perseorangan kebudajaan dan kesenian jang pikiran2nja memang telah dan diharapkan akan dapat seiring dengan pikiran2 PNI dilapangan kebudajaan', see 'LKN seiring dengan PNI dlm soal kebudajaan', Suluh Indonesia, 27-5-1959. 


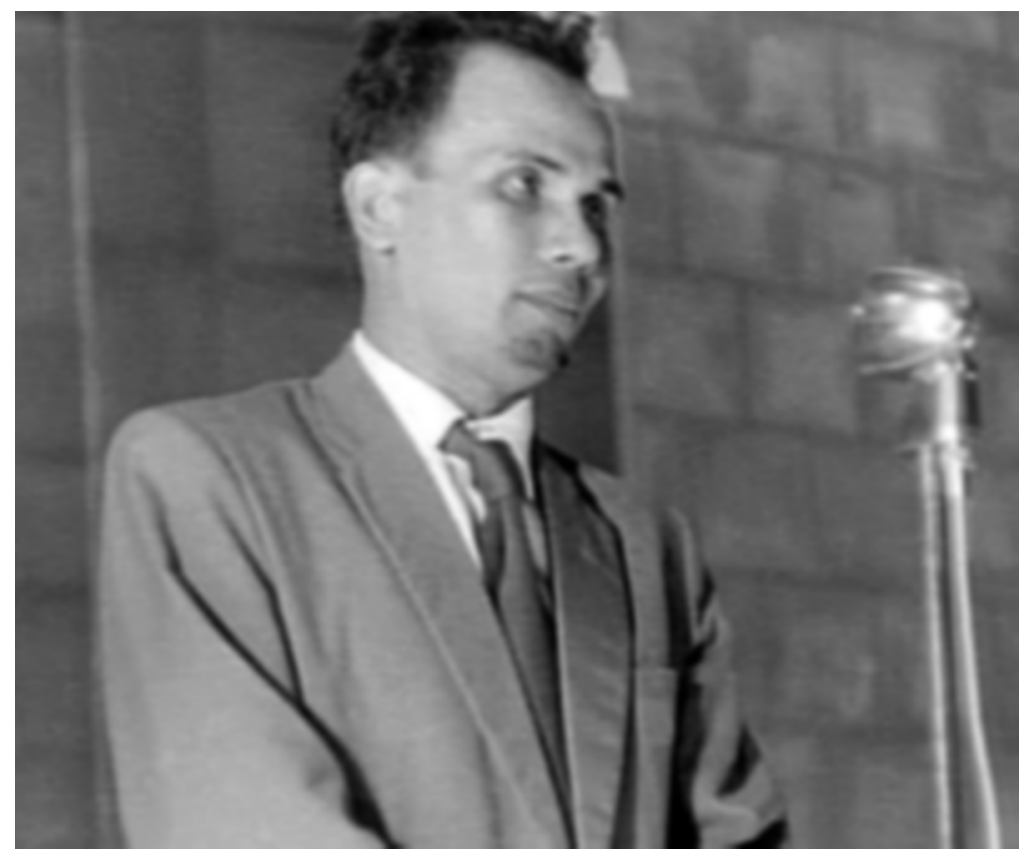

Sitor Situmorang, elected head of LKN, addresses the LKN Congress in Solo 1959. (Arsip Nasional RI, Gelora Indonesia reel 375)

President Soekarno was invited to open the LKN Congress but was absent because he was on an official visit to Brazil. Instead, he sent a page long speech to the Congress, a copy of which was published on the front page of the PNI-affiliated Jakarta newspaper, Suluh Indonesia, on 20 May 1959, the first day of the Congress. ${ }^{7}$ In his speech, Soekarno endorsed the Congress by encouraging artists to 'use your art as a tool for development' (Pakailah senimu sebagai alat pembangunan). He added that the arts should also become 'a driving force for the creation of a strong united nation which under Guided Democracy moves towards socialism à la Indonesia'. In addition to supporting the Congress, Soekarno donated some of his memorabilia to the committee to be auctioned to generate funds for LKN (Bu Har 1959).

7 Soekarno's speech was reproduced in 'Laporan kongres LKN'.

8 '[t]enaga pendorong pula bagi tertjiptanja Negara Kesatuan jang kuat jang dengan Demokrasi Terpimpin menudju ke sosialisme à la Indonesia'. The text of the President's speech was reproduced in the Congress booklet. 
The Solo Congress was attended by 150 participants, comprising delegates from 21 provinces, a fact that suggests that LKN had been in existence in almost all provinces of Indonesia prior to the declaration of the Central LKN. The Congress was also attended by observers and foreign guests including cultural attachés from India, America, Canada, and Yugoslavia. The committee went to great efforts to make the Congress a national event that could attract wide public attention. Pre-Congress activities began on 8 May in Jakarta with a heroic and festive ceremony attended by PNI leaders which included the handing over of LKN flags and banners to be carried by relay to Solo. The relay was supported by sympathisers of PNI, branch members and other affiliated organizations in every town it passed through on the 900 kilometre journey. The relay reached Solo on 19 May, one day before the Congress began. More elaborate cultural events were organized to mark the Congress, including a lively cultural parade on the theme of Bhinneka Tunggal Ika (Unity in Diversity) and three nights of performances by LKN regional delegations, all of which attracted a great crowd. A newspaper report noted that the town of Solo "was enveloped in a "festival of arts"' (Solo diliputi 'pesta seni'). ${ }^{9}$ It was in such a lively arts and cultural festival that the Central LKN was born.

Unlike LEKRA, which was first established at the national level in 1950 and then followed by the formation of its regional branches throughout Indonesia, the Central LKN was formed after the prior existence in some regions of the organization under the same name. Before the Solo Congress, LKN had already existed as one of many organizations affiliated to the PNI. The branch in the city of Solo, for example, already existed in 1955, while Bali already in 1956 had what was called the Denpasar branch of LKN. ${ }^{10}$ There were also organizations called LKN in North Sumatra, Central Java and Makassar, but there was no close relationship between them. All of these LKN organizations were affiliated to the PNI in their respective regions. Besides LKN, the PNI also had many other affiliated organizations including Pemuda Marhaenis (Marhaenist Youth), Wanita Marhaenis (Marhaenist Women), and Gerakan Mahasiswa Nasional Indonesia (GMNI, Indonesian National Students' Movement). Collectively, including LKN, these organizations were called the Marhaenist Front. There was a loose organizational relationship between organizations in one region and another, but they all shared one ideology, which was 'Marhaenism', the ideology of their parent organization, PNI.

9 'Kongres Lembaga Kebudajaan Nasional dimulai', Suluh Indonesia, 2-5-1959.

10 See the news section 'Berita kebudayaan' in Budaya 5-9 (September 1956):420. See also the Solo Congress booklet, especially the list of committee members that includes three Balinese names (1959:13). 
The term 'Marhaenism' was adopted by Soekarno in the 1920s from the name of a poor farmer, Marhaen, who suffered a great deal and did not have enough to live on. Sukarno met this farmer and turned his name into a concept 'to describe the destitute People of Indonesia' (Feith and Castles 1970:157). Marhaen is often loosely associated with the word 'proletar', (proletariat) the Marxist term for labourers and working class people, although the two are not quite equivalent. In his speech entitled 'Marhaen and Proletarian' which was delivered at a PNI gathering on 3 July 1957, Soekarno reintroduced Marhaenism as a way of talking about the people of Indonesia, who may own their land and their tools of production, but still remain desperately poor because they are subject to an exploitative system. Soekarno said 'almost all of the People of Indonesia are Marhaen' (Feith and Castles 1970:157).

In an important national meeting on 25 August 1964 in Jakarta, LKN once again emphasized its position as an institute fully committed to 'implementing Soekarno's guidelines in the field of culture' (melaksanakan garis besar Bung Karno dibidang kebudajaan). ${ }^{11}$ The principles emerging from this meeting make it accurate to say that LKN was a Soekarnoist cultural institution (Foulcher 1994:3).

LKN members reflected the spirit of Marhaenism in drama, prose and poetry. They adopted the spirit of Marhaenism in various contexts but mostly focused on two aspects, namely the importance of nationalism and the People's struggle. For instance, the first dramatic production by the LKN Theatre Institute (Lembaga Drama LKN) entitled Djangan takut dilanda ombak (Don't be afraid of being swept away by waves), ${ }^{12}$ performed on 2-4 September 1964 in the Gedung Kesenian Jakarta, can be seen as a typical example of a play that emphasizes the importance of the People's struggle against oppression and exploitation. The play, based on a script by Motinggo Boesje (1937-1999), describes the struggle of a group of poor fishermen to free themselves from the exploitation of a greedy money lender. The happy ending of this story clearly suggests the sympathy LKN artists felt towards lower class people. The characterization of the poor fishermen in this play is symbolic of the hardship and untiring struggle of the Marhaen. Sitor Situmorang, who in 1963 said he was proud to call himself a writer active in the field of politics, also made clear the struggle and hardship faced by poor farmers, as shown in one of his poems: ${ }^{13}$

11 'Hasil musjawarah seniman2 LKN', Suluh Indonesia, 2-9-1964.

12 'Djangan takut dilanda ombak', Harian Rakjat, 29-11-1964.

13 This poem was quoted by a member of LKN Bali, I Wayan Warna, in his article 'Menudju Sastera Marhaenis', Suluh Indonesia, 8-5-1966 and 15-5-1966. 


\begin{tabular}{|l|l|}
\hline Hiduplah, hidup & Long live the poor! \\
\hline $\begin{array}{l}\text { Kaum melarat, kaum penggarap } \\
\text { tanah tertjinta } \\
\text { Karena tjinta pada hidup } \\
\text { Tak pernah menunggu perintah }\end{array}$ & You farmers of this much loved land \\
Apalagi dari tuan tanah & You whose love of life \\
\hline
\end{tabular}

Whereas LKN and LEKRA shared themes dealing with the People's struggle and leftist ideology, in terms of religious values they showed a significant point of difference. LEKRA was perceived to support atheism because it was seen as an instrument of the PKI. LKN's position against atheism, however, was clear. As a secular organization, LKN took no stand on matters of religion. However, its support for Pancasila (which includes belief in God as the first principle) as part of the ideological underpinning of Indonesian nationalism meant that it did not provoke hostility from religious organizations. It was also an important contributor to the organization's acceptability in Bali.

\section{THE BALI BRANCH OF LKN}

As stated above, LKN was already in existence in Bali in September 1956, around three years before the Solo Congress. LKN Bali had several sections including gamelan music, dance, drama, literature, visual arts and film. Little is known about the activities sponsored by the organization, but from the areas of interest, it appears to have paid attention to both traditional and modern arts. LKN Bali attended the Solo Congress with great enthusiasm, which can be judged from the number of Balinese participants in the Congress. Transported by bus from Bali to Solo, the LKN Bali delegation consisted of fifty people including 'a number of special dancers' and gamelan musicians. ${ }^{14}$ On the way to Solo, they were invited to perform in Banyuwangi, East Java, for two nights, which turned out 'to be a great success'. In Solo, they were joined by a couple of Balinese students who were studying at the Solo Arts College and members of the local committee for performing arts. Balinese delegates took part in the Bhinneka Tunggal Ika cultural parade and

14 'Rombongan LKN bertolak ke Solo; Sedjumlah penari2 istimewa dan djuru gambel Bali turut meriahkan', Suara Indonesia, 19-5-1959. 
in the performing arts nights. The appearance and performance of Bali delegates was one of the highlights of the Congress arts festival.

After the 1959 Solo congress, a 'new' LKN Bali was established. The leader of PNI Bali appointed Merta Pastime (b. 1929), a civil servant and active member of PNI Bali, as the head of the LKN Bali. In a 2008 interview, Merta Pastime recalled that he was appointed as the head LKN Bali not because he had any personal interest or background in arts and culture but because he had been an active member of PNI Bali. ${ }^{15}$ This suggests that PNI Bali was intent on securing full control of the organization. In the following years, district branches of LKN were established throughout Bali from district to village level, paralleling the branch structure of the PNI.

Like elsewhere in Indonesia, in Bali too LKN became the cultural arm of the PNI. Arts and cultural activities of the party were concentrated on or became the responsibility of LKN. In party celebrations, inauguration of leaders of the Marhaenist Front, and at political rallies, the LKN automatically became the body responsible for performing arts and entertainment. During a three-day celebration of the 38th anniversary of the PNI in Tabanan in 1965, for example, the LKN Tabanan branch performed dance and drama for the entire three days, beginning at seven o'clock in the evening and lasting until dawn, attracting a large crowd and enlivening the celebration. ${ }^{16}$ In the parade watched by 300,000 people, ${ }^{17}$ a drum band group of Marhaenist children (putra/putri Marhaenis) from Banyuwangi also participated, suggesting a close connection between the Front Marhaenis of Tabanan or Bali and Banyuwangi. ${ }^{18}$ It is possible that the performance by LKN Bali delegates in Banyuwangi years earlier when they were on their way to the Solo Congress may have been the origin of this connection.

LKN AND CULTURAL POLITICS

The activities of LKN Bali were affected by cultural politics at both national and local levels. In 1963, President Soekarno declared his campaign of Confrontation against Malaysia, stating that the newly formed nation was a puppet state of British neo-imperialism and arguing that British presence in Malaysia or Southeast Asia in gen-

15 Interview in Denpasar, 19-12-2008.

16 'Tabanan bermandikan tjahaja banteng', Suara Indonesia, 3-8-1965.

17 'Tabanan bermandikan tjahaja banteng', Suara Indonesia, 3-8-1965.

18 'Tahukah Anda?', Suara Indonesia, 2-8-1965. 
eral would give Britain power to control the region and threaten the independence of Indonesia. Through a provocative campaign of 'Ganyang Malaysia' ('Crush Malaysia'), Soekarno stoked the spirit of nationalism and anti-neo-colonialism among the Indonesian people. LKN Bali actively promoted the spirit of the campaign through its arts and cultural activities, as I discuss further below, thus showing the unreserved commitment of LKN as a Soekarnoist cultural institution.

When in 1963-1964 there was tension at the national level between revolutionary cultural institutions and supporters of the Cultural Manifesto, the activities of LKN Bali were also affected. However, unlike the case of 'Crush Malaysia' where LEKRA and LKN in Bali were united in support of Soekarno's campaign, as they were at the national level, the position of LKN Bali in relation to the Cultural Manifesto was less predictable. Initially, a number of young Balinese writers who were members of LKN Bali including Raka Santeri (b. 1941) and Judha Paniek (1942-199?) became interested in the Cultural Manifesto group because they saw that it would support them in their opposition to LEKRA Bali. Both of these young writers received a mandate to disseminate the principles of the Manifesto among Balinese activists. ${ }^{19}$ They were also appointed as Bali regional coordinators for the Konferensi Karyawan Pengarang Se Indonesia (KKPSI, All-Indonesian Writers' Conference), which was planned for March 1964 and organized by right-wing groups including Cultural Manifesto supporters with backing from the Indonesian army. ${ }^{20}$ In a 1996 interview, Raka Santeri recalled how members of LEKRA frequently verbally attacked him and Judha Paniek at various political rallies. ${ }^{21}$ However, after the central body of LKN allied with LEKRA and other left-wing organizations to attack the Cultural Manifesto, all members of LKN including those in Bali had to follow the organization's directive. As members of LKN Bali, Raka Santeri and Judha Paniek were forced to withdraw their support for the Manifesto. Organizational protection at that time was very important, thus Raka Santeri and Judha Paniek had no other choice except to follow the instruction from the Central LKN. They subsequently refused to be regional coordinators for the KKPSI. ${ }^{22}$

19 'Seniman 15 kota menyokong Manifes Kebudayaan', Sastra No. 9/10 Th III-1963, quoted in Taufik Ismail and Moeljanto 1995:436-7. In this article Raka Santeri and Judha Paniek are named as supporters of the Manifes Kebudayaan. [The Ismail-Moeljanto citation of Sastra, as it appears above, seems to be incorrect, as we were unable to trace this article according to this citation. Eds.]

20 For a complete list of convenors and participants in the KKPI, see Taufik Ismail and Moeljanto 1995:441-5.

21 Interview in Denpasar, January 1996.

22 'Tiga pengarang Bali menolak djadi koordinator KK-PSI', Bintang Timur, 5-3-1964, quoted in Taufik Ismail and Moeljanto 1995:309. 
Although at the national level LEKRA and LKN took the same position in attacking the Manifesto, in Bali the dynamics of local politics meant that their relationship was full of tension. After the Cultural Manifesto was banned, the tension between LEKRA and LKN became very fierce, reflecting the conflict between the PKI and PNI respectively. The PKI and the PNI had been the two main political parties in Bali since the mid-1950s. By 1965, Bali's politics 'had become sharply polarized between the PNI and the PKI and their respective allies at the local and national levels' (Robinson 1995:212). The conflict between these two parties arose due to the poor implementation of the principles of NASAKOM by President Soekarno and the Governor of Bali. NASAKOM, an acronym of nationalism (nasionalisme), religion (agama), and communism (komunisme), was Soekarno's political strategy designed to reconcile the interests of the nation's three main factions. In practice, every level of social and political activity had to comprise elements of NASAKOM through a political strategy known as Nasakomisasi (Nasakomization).

PNI and LKN were the nationalist element of NASAKOM. In March 1965, writers and cultural activists in Bali formed a NASAKOM-based organization called the NASAKOM Arts and Drama Team (Tim Seni dan Drama Nasakom) led by Raka Santeri (LKN) and MS Asrori (LESBUMI). Abang Kaler (LEKRA) held the position of secretary and M. Pasek Arsana (from Genderang Budaja Swastika, a Hindu-based cultural organization) was treasurer. A representative from LESBI (Lembaga Seni Budaja Indonesia, Institute for Indonesian Arts and Culture, affiliated to PARTINDO) was invited but did not turn up to the meeting. The goals set by the NASAKOM Arts and Drama Team were 'to tighten cooperation between NASAKOM mass cultural organizations in implementing their Revolutionary duties and to move towards a just and prosperous socialist Indonesia based on Pancasila'. ${ }^{23}$ This organization planned cultural activities to commemorate the 10th anniversary of the 1955 Asia-Africa Conference, but no information has come to light as to whether this plan was realized. Newspaper reports, however, indicate cultural activities were carried out by groups that were part of the NASA$\mathrm{KOM}$ team, such as those of the Genderang Budaja Swastika that staged drama performances in Bali and the neighbouring island of Lombok.

23 ' $[\mathrm{m}]$ empererat kerdja sama di antara ormas-ormas kebudajaan Nasakom dalam melaksanakan tugas-tugas Revolusi menudju masjarakat sosialis Indonesia yang adil dan makmur berdasarkan Pantjasila', see ‘Team seni \& drama Nasakom', Suara Indonesia, 18-3-1965. 
But despite these attempts to bring the three NASAKOM factions together, it appeared that 'Nasakomization' in the cultural field was undermined by the power struggles going on between the organizations involved. Since Soekarno was close to the PKI and LEKRA, 'Nasakomization' in practice implied PKI infiltration into political and cultural activities. At the national level, the government privileged members of LEKRA, such as through the provision of more opportunities to take part in cultural exchanges and missions overseas, and in Bali the Governor of Bali, Anak Agung Bagus Sutedja, also gave the communists more support than the nationalists, thus upsetting an already precarious political balance. ${ }^{24}$ Evidence of this, in relation to cultural activities, is that the governor supported the appointment of members of PKI and LEKRA to the local committee of the executive meeting of Afro-Asian Writers held in Bali in $1963,{ }^{25}$ while the nationalists, supposedly one of the elements of NASAKOM, were excluded. In addition, the Bali government often commissioned members of LEKRA to provide banners and posters for events or national celebrations, something that made members of LKN feel marginalized and led them to accuse the government of being unfair to elements of NASAKOM. In the lead up to the 10th anniversary celebrations of the Asia-Africa Conference in 1965, IGB Arthanegara (b. 1944) and other members of LKN Bali approached the Bali Provincial Government Secretary and falsely claimed that they had LEKRA's agreement to take the money that had been allocated for making posters for the celebration. While money was certainly needed for making posters, for Arthanegara and his friends from LKN what was more important was to pre-empt LEKRA and make sure that their ideas and slogans were printed on the posters. ${ }^{26}$

POLITICAL COMPETITION AND CULTURAL EXPRESSION

Given the particular strength of LKN in Bali, the question arises as to which organization, LEKRA or LKN, was the larger and more influential there. While there are no exact figures on membership

24 Anak Agung Bagus Sutedja (1923-1966?) disappeared, presumed murdered in the postOctober 1965 purges.

25 The local committee was led by I Gde Puger, the leader of PKI Bali. See 'Menjambut teman seperdjuangan', Harian Rakjat, 21-3-1963.

26 Interview with IGB Arthanegara, Denpasar, 2-1- 2009. 
numbers, LKN leaders estimate that their organization had a larger membership and more supporters than LEKRA in Bali because it extended right to the village level where supporters were more numerous than LEKRA's. However, although LEKRA had fewer members, their activists were more militant than LKN's, as former members of LKN admit. ${ }^{27}$ Members of LKN used the PNI daily Suara Indonesia to publicize their cultural activities, whereas LEKRA used Mingguan Fadjar. ${ }^{28}$

Given the fierce conflict between LEKRA and LKN, it should not surprise us to see that the cultural activities of LKN Bali and its branches throughout the island were full of war-like language and attitudes towards LEKRA. This war of words can be clearly seen in the cultural activities of LKN Bali. The dominant forms of cultural activism concerned literature and the performing arts, as both were used to articulate key points of PNI propaganda.

\section{LITERARY ACTIVITIES}

Members of LKN Bali were very active in literary publication and the performing arts. In the field of literature, young writers like Raka Santeri, Arthanegara, Judha Paniek, Rugeg Nataran (1930-?) and Niniek Berata (b. 1945) published many poems and short stories in Suara Indonesia (now Bali Post), the local newspaper affiliated to PNI Bali in the 1960s. The themes of their poetry and short stories strongly reflect the ideology of the PNI, the teachings of Soekarno and the politics of national revolution and anti-neocolonialism. The writers were proud of Soekarno's teachings and quoted them through repeated mention of terms such as 'Pancasila', 'marhaenism', 'nekolim' or 'anti-nekolim' (neo-colonialism), and 'revolusioner'. The name of Soekarno himself appears in many poems by LKN writers, which had already been the case in Bali from the early 1950s. As well as publishing their work in newspapers, writers also read at poetry reading competitions or political rallies and celebrations, thus maximizing the potential impact of poems reflecting a spirit of nationalist fever.

27 Interview with IGB Arthanegara, 2-1-2009, and with Gde Dharna, 14-1-2008.

28 According to Widminarko, a journalist for Suara Indonesia in the 1960s and pro PNI student activist, Mingguan Fadjar used a catchy motto 'membudayakan merah dan memerahkan budaya' or 'to make red politics an expression of culture and to make culture an expression of red politics'. Personal communication with Widminarko, 12-8-2009. Widminarko still writes for the Bali Post. 
The message of a poem was regarded as being more important than its form and aesthetic qualities. One typical example of the propaganda poetry produced by LKN writers at this time is Arthanegara's poem Laut (Sea) that contains this provocative line:

djangan biarkan bumi ini didjamah ummat tak ber-Tuhan /../ do not let this land be taken by atheists /../

karena mereka adalah musuh terbesar Pantjasila they are the greatest enemy of Pancasila

(Arthanegara 1963)

The nationalist tone of the poem expresses the importance of defending the homeland, Indonesia. It not only emphasizes the importance of Pancasila as the basic principle of the Indonesian state, but also explicitly attacks atheism, which in Bali was associated with communism. It clearly reflects LKN's hostility towards LEKRA. Besides Pancasila, the term Marhaen and its variants also frequently appeared in titles of poetry by LKN members, such as Padamu Marhaen (For you Marhaen) by Manik Arsenaya, ${ }^{29}$ Kepada Suswati Marhaenis (For Marhaenist army volunteers) by Niniek Berata, ${ }^{30}$ and Anak Marhaen (Children of Marhaen) by Ngurah Parsua (b. 1945). ${ }^{31}$

During Confrontation against Malaysia, newspapers in Bali, especially Suara Indonesia, frequently published stories about this national campaign, in which students and youth were encouraged to volunteer to be sent to the battlefield in North Kalimantan (Kaltara). Soekarno's propaganda attack on Malaysia and his determination to crush neo-colonialism, known by the term Dwikora or the People's Double Command, was enthusiastically welcomed in Bali. Many students, male and female, came forward as volunteers. Members of the Marhaenist Front formed the Sukarelawati Wanita Marhaenis (Marhaenist Women Volunteers). Volunteers received basic military training including how to use weapons and throw grenades. In May 1964, a local newspaper stated Bali was ready to send 15,000 combatants to North Kalimantan. ${ }^{32}$ Indonesian troops did fight in North Kalimantan, but according to Widminarko (b. 1942),

29 Suara Indonesia, 31-10-1964.

30 Suara Indonesia, 7-3-1965. Suswati stands for sukarelawan and sukarelawati, meaning male volunteer and female volunteer. It refers to those who were ready to go to the battlefield in North Borneo to attack Malaysia during Confrontation in the early 1960s.

31 Suluh Marhaen, 7-5-1966.

32 'Bali siap kirimkan brigade tempur', Suara Indonesia 30-5-1964. 
a pro-PNI student and volunteer who received military training in Bali, the volunteers from Bali were never actually sent to North Kalimantan, and all the preparations on the island proved to be part of President Soekarno's overall show of force aimed at threatening the British 'puppet state' of Malaysia. ${ }^{33}$

On 2 February 1964, a newly established group named Gong Kronik supported by the Nationalist Front held a performance in Denpasar designed to fire the Crush Malaysia spirit. ${ }^{34}$ A Balinese LEKRA activist, Putu Oka Sukanta, who was the leader of Gong Kronik, played important role in the program, which included drama and readings of poems expressing the spirit of nationalism and anti-colonialism. ${ }^{35} \mathrm{In}$ addition to poems by nationallyestablished poets such as Chairil Anwar, and work by LEKRA poets such as Agam Wispi (1930-2003) and H.R. Bandaharo (1917-1993), they also read poems by Putu Oka on the theme of Crush Malaysia including Mengganjang Malaysia (Crush Malaysia) and Salam untuk Kaltar (Greetings for North Kalimantan). In addition to this live performance, activists also read poems on radio to provoke the spirit of 'Ganyang Malaysia' and anti-neo-colonialism. Plays performed during the program included those of LEKRA writers such as P.H. Muid's Kemarau (Dry season) and Zubir A.A.'s Lagu subuh (Song of dawn) which Putu Oka directed. ${ }^{36}$ In terms of the propaganda of anti-colonialism and Crush Malaysia, LKN writers shared the same ideological outlook as LEKRA.

LKN Bali writers quickly adopted and articulated the campaign against Malaysia through propaganda literature. Two examples are poems Buat pedjuang Kalimantan Utara (To the North Kalimantan heroes) (1964) by Asa K. and Pedjuang Kaltara (North Kalimantan heroes) (1965) by Kawi Yasa. Asa's poem supports the struggle of the people of North Kalimantan to crush the British and their federated state of Malaysia into dust ('ganjang-ganjang hingga djadi debu'). Yasa's poem calls for the eradication of neo-colonialism not only from Indonesian territory but also from Borneo and from the states of Asia and Africa. It emphasizes the spirit of unity among member countries of the Non-Aligned Movement in which Indonesia and Soekarno played an important role. The following extract from the poem reflects the optimism and over-confidence of Soekarno's propaganda in abolishing neo-colonialism in North Kalimantan:

33 Email communication with Widminarko, 7-8- 2009.

34 'Malam drama dan puisi; Mengganjang "Malaysia" di Denpasar', Harian Rakjat 9-2-1964.

35 Putu Oka Sukanta (b. 1939), poet, short-story and novelist, was involved with LEKRA and after the 1965 coup held as political prisoner from 1966-1976.

36 For a discussion of these two plays, see Bodden in this volume. 


\begin{tabular}{|l|l|}
\hline $\begin{array}{l}\text { Pengorbanan... kemenangan... } \\
\text { kemerdekaan }\end{array}$ & Sacrifice... victory... independence \\
$\begin{array}{l}\text { Kemerdekaan rakjat Kaltara... rakjat } \\
\text { AA }\end{array}$ & $\begin{array}{l}\text { Independence for the people of North } \\
\text { Kalimantan... people of Asia Africa }\end{array}$ \\
$\begin{array}{l}\text { Kemerdekaan rakjat sedunia... } \\
\text { menudju... Dunia Baru }\end{array}$ & $\begin{array}{l}\text { Independence for people in the whole } \\
\text { world... to move towards a New World } \\
\text { (Kawi Yasa 1965) }\end{array}$ \\
\hline
\end{tabular}

The spirit of revolution and anti neo-colonialism was expressed in many poems by members of LKN Bali. Published in Suara Indonesia, the newspaper affiliated to the PNI, these writers were encouraged by the editor of the newspaper's literary column to write poetry and short stories on such revolutionary themes. In one note, the editor encouraged young writers 'to become the writers who make the greatest contribution to the Revolution, heading towards the glorious society of Socialist Pantjasila'. ${ }^{37}$ In the same note, the editor criticized a short story by a young writer Dangin Harnama (1943-1996) that ends with a female character committing suicide, emphasizing that he should not write stories with such a pessimistic tone. The editor stressed that writers should 'help complete our Revolution with their works'. ${ }^{38}$

As though reflecting this editor's comment, Arthanegara published a short story entitled Sri Kandi (the name of a heroine) that takes the subject matter of 'Ganyang Malaysia'. ${ }^{39}$ This story opens with a quotation from the well-known speech of Soekarno entitled Tahun vivere pericoloso (The year of living dangerously), delivered on 17 August 1964 in the midst of the campaign to attack Malaysia. The words are:

'I warn all Imperialists everywhere: do not touch the territory of the Republic of Indonesia, do not touch!' ${ }^{40}$

The main character in the story is a female named Nana Heriantini who goes as a volunteer (sukarelawati) to the battlefield of North

37 '[u]ntuk mendjadi penulis jang paling banjak menjumbang untuk Revolusi menudju masjarakat Sosialisme Pantjasila jang djaja', see 'Taman Muda Remaja', Suara Indonesia, 22-8-1964.

38 'Membantu penjelesaian Revolusi kita ini dengan karja2mu', Suara Indonesia, 22-8-1964, pp. 3.

39 Suara Indonesia, 10-10-1964. The common spelling of this word is Srikandi, as one word.

40 'Saja peringatkan kepada kaum Imperialis manapun: djangan mendjamah wilajah Republik Indonesia, djangan mendjamah!' 
Kalimantan to help the people there fight against British troops. She is depicted as a brave soldier who manages to gun down five enemies. Although the story touches on the sadness of the heroine when she remembers her parents and boyfriend back home, overall it has a strong optimistic tone evident from the heroine's vow to return home to find a fiancé only 'once the neo-colonialist project in Malaysia is completely buried' (kalau njata-njata projek neokolonialis Malaysia telah terkubur habis). This theme is also evident in Made Ariaka's short story Ke perbatasan (Going to the border) ${ }^{41}$ In this story, the male character (Made Sulah) has to cut his eight days' leave to four following the arrival of a telegram that asks him to go to Surabaya to join other volunteers going to the border region of North Kalimantan. Realizing that she is going to be left behind, Erawati (Sulah's fiancée) is initially confused and sad, but after she becomes aware that her boyfriend is involved in a national mission, she gives him her full support:

Crush neo-colonialism. Back up the struggle of the People of North Kalimantan. Please do not return until the Puppet State of Malaysia has been crushed. ${ }^{42}$

Love was always a subtheme in the revolutionary poems and short stories by LKN Bali members. This is understandable because most of them were young at that time. Arthanegara, for example, was only twenty years old when he wrote Sri Kandi. Another active poet, Paulus J.M. Jauwboenbing (b. 1945) (also known as Paulus Yos Adi Riyadi) was only nineteen years old when he published his poem Tjeritera buat Sri Hardini (A story for Sri Hardini) which includes the line 'I became a volunteer to crush Malaysia' (aku djadi sukarelawan mengganjang Malaysia).$^{43}$

Themes dealing with revolution and love were also apparent in the performing arts. At the national level, the spirit of 'Ganyang Malaysia' also inspired composers to create heroic songs to provoke sentiments of nationalism and anti-imperialism. Artistic and cultural activities in Bali were certainly influenced by national politics, but the relationship was also reciprocal because what happened in Bali also contributed to the ongoing nationalist fever throughout Indonesia.

41 Suara Indonesia, 9-5-1965.

42 'Tumpaslah Nekolim. Bantu perdjoangan Rakjat Kaltara. Kalau Negara Boneka Malaysia belum tertumpas djangan kembali.'

43 Suara Indonesia, 10-10-1964. 
PERFORMING ARTS

Besides literature, LKN Bali was also very active in the performing arts, both traditional and modern genres. One of the popular traditional genres used to articulate the spirit of national revolutionary was janger, a type of performance that presents stories, and also social commentary, through songs and some dialogue. Janger started to become popular in the 1920s (De Zoete and Spies 1958), and flourished in the 1960s when it was used to convey social and political propaganda (Putu Setia 1987; Orenstein 1971). The language used in the dialogue of janger was a mixture of Balinese and Indonesian (Putu Setia 1987:95). Images of janger as a performance expressing the spirit of nationalism appear in a novel by Nur Sutan Iskandar (1893-1975) titled Jangir Bali (1964).$^{44}$ Although published in the 1960s, the novel is set in the 1930s against the backdrop of the emerging nationalist movement in Bali. It tells the story of a love affair between a nationalist youth from Java and a Balinese janger dancer whose performances spread the spirit of nationalism (Darma Putra 2008:95, footnote 22). It is a work of fiction, but it suggests that the use of janger as a vehicle of political propaganda originated in the colonial period. There is a clear thematic relationship between this janger story and themes that appeared at this time in short stories and poems. Balinese literature and performing arts have always been pre-occupied by social issues, but in the 1950s and 1960s social commentary came to mean political and social propaganda.

In the early 1960s both LKN and LEKRA frequently commissioned performances of janger for party celebrations or at the inauguration ceremonies of party leaders or social organizations. Through the songs in the janger, these two competing organizations often expressed pride in the ideology of their organizations. LEKRA's janger echoed the spirit of classless communist ideology (sama rasa, sama rata), while LKN's janger songs contained lyrics espousing the victory of the Marhaen and the glory of Pancasila (marhaen menang Pancasila jaya) (Putu Setia 1987:95). Metaphor was often used in the songs to mock opponents. For example, the song Buah buni (buni fruit) by Gde Dharna (b. 1931), the head of LKN Buleleng, was used by LKN to mock LEKRA through the politics of colour. The song says how red buni fruit taste sour, while black buni fruit taste very sweet - red being the colour associated with the PKI and LEKRA, while black was the colour of PNI and LKN. The song was explicitly used by LKN and the PNI to attack 
what they saw as the cunning, immaturity, and dishonesty of both LEKRA and the PKI. In this way, performances by members of LKN and LEKRA not only reflected but also fuelled the tension between the two political groupings.

Apart from janger, drama was also used by nationalist artists to both entertain the public and express social and political propaganda. ${ }^{45}$ The Hindu-based theatre group, Genderang Budaya Swastika, held drama performances in several places in Bali, as well as in Lombok. These performances told stories such as Mayadenawa, a tale about a defeated demon who forbade his people to pray to the gods, which was performed to encourage people to turn away from the atheism that communist influence had promoted (Darma Putra 2008:99100). The Mayadenawa performance was first created in 1959 and by 1966 it had been staged more than ten times in Bali and twice in Lombok, in 1962 and 1963. The first tour to Lombok, commissioned by the Hindu Council, was to celebrate the Hindu holidays Galungan and Kuningan, while the second was for a charity night for the Lombok branch of the Palang Merah Indonesia (PMI, Indonesian Red Cross). ${ }^{46}$ After 1966, Mayadenawa continued to be performed and was always 'a great success' (Mayun 1967:2-3). It gradually became an inspirational form of Balinese drama gong, a spoken drama with gamelan accompaniment initially using a mixture of Indonesian and Balinese languages, with actors wearing Balinese attire, and in its later development, towards the end of the 1960s, performed entirely in Balinese (DeBoer 1996; Putu Setia 1987; Darma Putra 2008).

One activity begun by LKN Bali in early 1965 that continued long after the coup later that year and the subsequent banning of the PKI and LEKRA, was the establishment of a drama festival and accompanying poetry reading competition. The first 'Drama festival and poetry reading competition', was held from 5 to 10 March 1965. Six groups attended, with only the districts of Gianyar and Singaraja not represented. The absence of these two districts was much regretted because both had long experience in drama and other performing arts (Buddy Satria 1965:3). Scripts performed for the festival were plays by nationally known writers such as Motinggo Boesje, Kirdjomuljo (1930-2000) and Singgih Hadi, as well as a local playwright, Heman Negara (1943-1991), all of whom were members of LKN. Poems on nationalistic themes were chosen for the poetry reading competition. All arts and entertainment activities became arenas for LKN to promote the political outlooks of its parent organization, the PNI.

45 'Theatre Denpasar menghibur ke desa', Suara Indonesia, 15-8-1964.

46 'Mayadenawa di Pedjeng', Suluh Marhaen, Minggu, 29-5-1966. 
The genesis of the drama festival was the visit of a theatre group from LKN Yogya between December 1964 and January 1965. The goal of their Bali trip was to 'arouse the drama-minded spirit in Bali' ('membangkitkan drama minded di Bali'). During the visit, LKN Yogyakarta, led by Buddy Satria, gave performances in various towns and cities, including Singaraja, Tabanan and Denpasar. The group performed two stories, Api di Lembah Mati (Fire in the Valley of Death) by Singgih Hadi and Malam pengantin di Bukit Kera (Wedding night in Bukit Kera) by Motinggo Boesje (Nana Tantienna 1965). Reflecting on the success of LKN Yogyakarta performances in Bali, Widjaja (now known as Putu Wijaya), the Balinese dramatist who was then based in Yogyakarta, wrote in Suara Indonesia of the need for Bali to hold a drama festival, not only because Bali had under-utilized potential in this field, but also because drama could be used to disseminate ideology (paham) in a time of Confrontation. ${ }^{47}$ Bali quickly responded to this suggestion, and within three months a five-day drama festival had been organized. It was held from 5-10 March 1965 and was such a success that LKN Bali decided to make it an annual event.

Buddy Satria, the leader of the LKN Yogya Drama Institute, came to Bali again in March 1965 specifically to observe the drama festival and poetry reading competition. As an observer, he published a series of six review articles in the local newspaper Suara Indonesia and praised the festival's success (Buddy Satria 1965). He discussed in detail the strengths and weaknesses of individual groups and their actors in terms of acting, directorship, vocal technique, blocking and interpretation of the play, concluding that Bali had many talented young dramatists. If they were willing to rehearse and perform more often, he said, the development of modern drama in Bali could outstrip developments in the main cities of Java. Satria also commented upon the Balinese-style carved trophy awarded to festival winners in place of the more common silver trophy, calling it 'an expression of national identity by LKN Bali' ${ }^{48}$ Modern-style theatre was not new to Balinese writers and cultural activists. In the early 1950s, students and cultural activists in Singaraja, north Bali, staged adaptations of works by national and international playwrights such as Utuy Tatang Sontani, ${ }^{49}$ Andre' Gide and Anton Chekhov (Sutedja-Liem 2000:163; Darma Putra 2008:97). Despite

47 Putu Widjaja 1965. Putu Wijaya is currently one of Indonesia's most prolific writers. In email communication (24-7-2009), he confirmed that he was the author of this article.

48 'Ini merupakan kepribadian nasional dari LKN Bali'. See Buddy Satria 1965.

49 The famous playwright Utuy Tatang Sontani (1920-1979), who wrote in both Sundanese and Indonesian, was associated with LEKRA and lived in exile after the events of 1965 . He died in Moscow. 
this, the influence from LKN Yogya remains significant because it was the direct incentive for LKN Bali to hold a drama festival.

The success of the March 1965 festival appears to have revitalized LKN Bali. After the festival, there was a renewed determination to be part of the development of Indonesian culture and national identity. This can be seen in a formal resolution in which members of the organization identified themselves as 'National Culture workers of Indonesia' ( para pekerdja Kebudajaan Nasional Indonesia), foregrounding their national, rather than their Balinese, identity. The resolution consisted of three points:

1. We National Culture Workers of Indonesia resolve to dedicate our art and ourselves to the completion of the Indonesian Revolution with Marhaenism as the commander;

2. We National Culture Workers of Indonesia believe and are fully aware that the Message of the People's Suffering must be the only source of works expressing Indonesian National culture;

3. We National Culture Workers of Indonesia resolve to develop the Culture of National Identity in the spirit of Pancasila. ${ }^{50}$

The spirit of nationalism in this resolution is a direct rearticulation of the political thinking of President Soekarno. The influence of Soekarno's teaching throughout Indonesia was profound, and nowhere was this more so than in Bali. Balinese people saw Soekarno as a true leader, not only because of his personal political charisma which was often linked to his mother being Balinese, but also because of the following enjoyed in Bali by the PNI, the political party he founded. In addition, Soekarno was seen to be proud of Balinese culture (Vickers 1989:175), something that was evident in the numerous opportunities he provided for Balinese artists to rep-

50 'Kebulatan tekad LKN seluruh Bali', Suara Indonesia, 13-3-1965. (1) Kami para pekerdja Kebudajaan Nasional Indonesia bertekad bulat untuk mengabdikan seni dan diri bagi penjelesaian Revolusi Indonesia dengan Marhaenisme sebagai panglimanja; (2) Kami para pekerdja Kebudajaan Nasional Indonesia mejakini dengan sadar sesadar-sadarnja bahwa Amanat Penderitaan Rakjat haruslah mendjadi satu-satunya sumber penggarapan karja-karja Kebudajaan Nasional Indonesia; (3) Kami para pekerdja Kebudajaan Nasional Indonesia bertekad bulat untuk mengembangkan Kebudajaan jang berkepribadian Nasional dan berdjiwa Pantjasila. 
resent Indonesian culture before state guests and as part of various overseas cultural missions. ${ }^{51}$

Following the coup of 30 September-1 October 1965, leftist activists and people considered to be sympathizers of the PKI in Bali were arrested, killed, or detained without trial (Robinson 1995). The massacres took place over almost all of Bali, especially in Denpasar and Singaraja. The victims, estimated to be in the thousands, included writers and artists. For instance, in Singaraja the poet, short story writer, journalist and LEKRA activist Putu Shanty was killed along with two of his children in December 1965. According to DeBoer, one result of the tragedy of mass murder in Bali was that attempts to continue the artistic activity faced a brief new reality in the shortage of talented dancers (DeBoer 1996). Even so, artistic life resumed immediately, albeit with a completely new cultural map with the Left and leftist expression silenced. LKN had to find a new position in this map.

After LEKRA was banned nationally in March 1966, LKN became unchallenged as the dominant cultural institution in Bali, and for a time its annual drama festivals continued without interruption. From 17-24 July 1966, LKN Bali held a drama gong festival and poetry reading competition week (pekan festival drama gong dan deklamasi). It was a continuation of the previous year's event, although modern drama was replaced by drama gong without any specific explanation given for the change. The 1966 festival was the first drama gong festival to be held since the 1965 coup. Its goal, in the nationalistic rhetoric of LKN's leader Merta Pastime, was to encourage artistic creativity as a contribution to a society that had been in the process of completing the Pancasila revolution. ${ }^{52}$ During the transition era to the New Order regime, the rhetoric and teachings of Soekarno still echoed in Bali, at least until mid1966. This can be seen from a resolution of the regional conference of LKN Bali that was published in Suluh Marhaen. One of the articles of the resolution stated that LKN Bali was committed 'to strengthen the Marhaenist ideology of Soekarno's teachings among cultural workers' ${ }^{53}$ Other evidence included poems published in the local newspapers which were dedicated to Bung Karno's teachings and others such as Ngurah Parsua's Anak Marhaen, ${ }^{54}$

\footnotetext{
51 For discussion of the overseas arts missions and the participation of Balinese artists, see Jennifer Lindsay and Irawati Durban Ardjo in this volume.

52 'Memperkuat ideology Marhaenism adjaran Bung Karno pada pekerdja2 kebudajaan'. See 'Pekan festival LKN success; Penggugah, penggerak, pelandjut dalam bidang kreasi', Suluh Marhaen, 26-7-1966.

53 'Hasil2 keputusan konperda V LKN Bali; Tentang politik kebudajaan', Suluh Marhaen, 24-71966.

54 Suara Indonesia, 7-5-1966.
} 
and Putu Widjaja's Salam bulan Djuni $i^{55}$ (Welcome June) which was written for the occasion of Soekarno's 65th birthday. By this time, however, Soekarno had been stripped of power, both unofficially and officially.

In addition, LKN Bali also held gamelan festivals. This festival was not a new idea as festivals of this kind had been held in Bali in the 1930s. The difference was that in the 1930s, the gamelan festival was sponsored by the local rajas, whereas in the 1960s it was organized by LKN and other organizations, such as the government-sponsored cultural organization, Madjelis Pertimbangan dan Pembinaan Kebudajaan (LISTIBIYA, Council for the Evaluation and Development of Culture). These festivals were usually attended by representatives of LKN at district or village level depending upon the level of the competition. The active role of LKN in Bali and its subordinate organizations from 1959 until the end of the 1960s enlivened the world of the arts and cultural life in Bali through a time of great political upheaval and social trauma. LKN Bali deserves credit for initiating the popularity of drama gong, which lasted from the late 1960s to the early 1990s.

Unlike LEKRA, LKN was never formally banned by the government. The former leader of the Central LKN, Sitor Situmorang, was jailed between 1967-1974 in the wake of the events of September-October 1965, but in Bali no prominent members of LKN were arrested. However as an organization, LKN gradually disappeared, in line with the policy of the New Order government to separate arts and culture from politics. Nowadays, some former members of LKN Bali, like Gde Dharna, Ngurah Parsua and Arthanegara, still produce works of literature and publish them in newspapers or book form, either in Balinese or Indonesian. Arthanegara recently published his first novel, Dunia kampus yang lain (Another campus world) (2007), a story about the experience of the author when he was studying in Beijing in the mid-1960s. Like the poems and short stories by Arthanegara in the 1960s, this novel also expresses a strong sense of nationalism. The narrator (who represents the voice of the author) decides to leave Beijing to return to Indonesia after he is told that the Communists were behind the September 1965 coup attempt. An interesting aspect of the novel is that it looks at the 1965 coup from the perspective of Indonesian students, diplomats and permanent residents who were in the People's Republic of China at that time (Darma Putra 2007). Although Arthanegara and other 
writers are no longer engaged in creative work as members of LKN or other arts and cultural organizations, and thus feel no obligation to voice the social and political agenda of a particular organization as they did in the past, their works are still inspired by a spirit of nationalism and heroism even though the contexts are not necessarily the same as the background to their works of the 1950 s and 1960s.

\section{CONCLUDING REMARKS}

This essay departs from the framework of nationally-oriented studies of cultural institutions in Indonesia in the period of the $1950 \mathrm{~s}$ and $1960 \mathrm{~s}$ by giving specific attention to the regional branches of LKN Bali and their cultural activities. Study of LKN is particularly interesting because its regional branches predated the existence of the Central LKN, and studying their activities reveals other aspects of cultural relations between region and 'centre' than those with which we are familiar from studies of LEKRA, for example. Regionally-focused study of LKN is also important because it enriches our understanding of the way the highly politicized climate of cultural activity in Indonesia at this time was as much a product of interactions between competing groups at the local level as it was the product of tensions at the national level.

LKN already existed as a cultural institution in Bali in the mid1950s. However, it became more active and politically-engaged in the early 1960s following the PNI's growing awareness of its potential for harnessing political support through cultural activities, in the same way that LEKRA was seen to be doing for the PKI. The dynamic growth of LKN Bali evolved out of three significant developments: first, access to the ideas and renewed energy that followed the re-establishment of LKN Bali as part of the Central LKN at the Solo Congress in 1959; second, the growing nationalist fever of this period, especially after President Soekarno declared the 'Ganyang Malaysia' campaign in 1963; and third, the power struggle that erupted between the two dominant political parties in Bali, the PNI and PKI, which extended to their affiliated cultural organizations, LKN and LEKRA respectively. Considering the frequent injunctions by President Soekarno and the leaders of PNI for the Indonesian people to dedicate themselves to the completion of the national revolution, the cultural activities of LKN Bali, and presumably also elsewhere in Indonesia, were 
highly preoccupied with social and political propaganda, rather than the development of art forms as such. In addition, newspaper editors encouraged writers to contribute to the completion of the revolution through their work. There was clear textual relationship between themes of political speech, performing arts and literary discourse.

The existence of LKN Bali enlivened the cultural activities on the island because members of the organization enthusiastically used a variety of traditional and modern art forms, literature and performing arts, to express the veritable fever of nationalistic sentiment that was fired by the ideological rhetoric and political campaigns of the period. Writers, actors and other cultural activists devoted their full attention to national issues and the projection of a sense of being Indonesian, leaving them with little room to express local issues of Balinese culture and identity. However, as is evident in their use of traditional performing arts such janger and drama gong, Balinese culture was an intrinsic part of their expression of Indonesian national culture.

In Bali, LKN and LEKRA were generally in conflict, even though they found common ground on some particular issues. LKN members' reaction to the Cultural Manifesto is a case in point, when members initially supported the Manifesto, but were later instructed by the central organization to join LEKRA in opposing it. Support for Soekarno's 'Ganyang Malaysia' propaganda campaign is another example of LKN and LEKRA sharing a common political stance. In the context of religion, however, LKN and LEKRA stood sharply opposed, with the former's endorsement of Pancasila implying an acceptance of 'belief in God', while LEKRA was perceived to support atheism, or at least LKN portrayed it in this way.

Unlike in other parts of Indonesia, in Bali LKN was at least as strong, if not stronger than LEKRA. The conflict between the two organizations, rather than being purely ideological was primarily politically motivated in accordance with the ambitions of the PNI and PKI respectively. Both wanted to tie their affiliated cultural bodies to party-political programs. The case of LKN Bali shows that in studying the cultural organizations of this period, it is important that we do not see any one of them in isolation. The relationships between organizations influenced their approaches to culture and their cultural activities at this time - and these relationships were different in different places in Indonesia. 


\section{REFERENCES}

Arthanegara

1963

'Laut', Suara Indonesia, (31 January).

Asa K.

1964

'Kalimantan Utara', Suara Indonesia, (31 October).

Buddy Satria

1965 'Sedikit catatan festival drama \& deklamasi LKN Bali', Suara Indonesia, (21 March).

$\mathrm{Bu} \mathrm{Har}$

1959 'Oleh-oleh dari kongres LKN', Suluh Indonesia, (27 May).

Choirotun Chisaan

2008 Lesbumi, strategi politik kebudayaan. Yogyakarta: LKiS.

Darma Putra, I Nyoman

2003 'Literature and politics; The development of LEKRA in Bali, 1950-1966', in: Thomas Reuter (ed.), The muted worlds of Bali; Social inequality and social change in the wake of the Indonesian crisis, pp. 54-85. London: Routledge Curzon.

2007 'Kisah mahasiswa Indonesia di Cina pada tahun 1960-an' (book review), Bali Post, (20 May).

2008 'Modern performing arts as a reflection of changing Balinese identity', Indonesia and the Malay World 36:104, 87-114.

DeBoer, Frederick E. (also Frederik E.)

1996 'Two modern Balinese theatre genres; Sendratari and drama Gong', in: Adrian Vickers (ed.), Being modern in Bali; Image and change, pp. 158-78. New Haven: Yale University Press.

Feith, Herbert and Lance Castles

1970

Indonesian political thinking 1945-1965. Ithaca: Cornell University Press.

Foulcher, Keith

1969 'A survey of events surrounding Manikebu; The struggle for cultural and intellectual freedom in Indonesian literature', Bijdragen tot de Taal-, Land-en Volkenkunde 125:429-65.

1986 Social commitment in literature and the arts; The Indonesian 'Institute of people's culture' 1950-1965. Victoria: Centre of Southeast Asian Studies, Monash University.

1994

'The manifesto is not dead'; Indonesian literary polemics thirty years on. Clayton, Vic.: Centre of Southeast Asian Studies, Monash University. 
Goenawan Mohamad

1988

The 'Cultural Manifesto' affair; Literature and politics in Indonesia in the 1960's; A signatory's view. Clayton, Vic.: Centre of Southeast Asian Studies, Monash University.

Kawi Yasa

1965

'Pedjuang Kaltara', Suara Indonesia, (15 August).

Mayun, I B

1967

'Catatan kecil terhadap pementasan drama klasik Maya Danawa', Suluh Marhaen, (17 September).

Nana Tantienna

1965

'Drama tour LDN Jogja di Bali', Suara Indonesia, (17 January).

Nur Sutan Iskandar

1964 Jangir Bali. Jakarta: Balai Pustaka.

Orenstein, Ruby

1971 Gamelan gong kebyar; The development of a Balinese musical tradition. PhD thesis, University of California, Los Angeles.

Putu Setia

1987 Menggugat Bali. Cetakan kedua. Jakarta: Grafitti Press. [First edition 1986.]

Putu Widjaja

1965

'Festival drama LKN seluruh Bali di Denpasar', Suara Indonesia, (24 January).

Rhoma Dwi AriaYuliantri and Muhidin M Dahlan (eds)

2008a Lekra tak membakar buku; Suara senyap lembar kebudayaan Harian Rakyat 1950-1965. Yogyakarta: Merakesumba.

2008b Laporan dari bawah; Sehimpunan cerita pendek LEKRA 19501965. Yogyakarta: Merakesumba.

Robinson, Geoffrey

1995 The dark side of paradise; Political violence in Bali. Ithaca: Cornell University Press.

Sutedja-Liem, Maya

2000 'Nyoman Rasta Sindhu; Humanity in Balineseness', in:

Adrian Vickers and I Nyoman Darma Putra with Michele

Ford (eds), To change Bali, pp. 155-82. Denpasar: Bali Post and Institute of Social Change and Critical Inquiry, University of Wollongong.

Taufik Ismail and D.S. Moeljanto (eds)

1995 Prahara budaya; Kilas-balik ofensif LEKRA/PKI dkk. Jakarta:

Mizan dan HU Republika. 
Vickers, Adrian

1989 Bali; A paradise created. Ringwood: Penguin.

Yahaya Ismail

1972 Pertumbuhan, perkembangan dan kejatuhan LEKRA di Indonesia. Kuala Lumpur: Dewan Bahasa dan Pustaka.

Zoete, Beryl de and Walter Spies

1958

Dance and drama in Bali. New York: Thomas Yoseloff. [First published 1938.] 